ISSN 1392-3196 / e-ISSN 2335-8947

Zemdirbyste-Agriculture, vol. 108, No. 4 (2021), p. 377-382

DOI 10.13080/z-a.2021.108.048

\title{
In vitro propagation of Passiflora edulis through internodal segments as affected by medium composition
}

\author{
Natalija BURBULIS, Aušra BLINSTRUBIENĖ, Aistis PETRUŠKEVIČIUS \\ Vytautas Magnus University Agriculture Academy \\ Donelaičio 58, 44248 Kaunas, Lithuania \\ E-mail: natalija.burbulis@vdu.lt
}

\begin{abstract}
The aim of the experiment was to evaluate the effect of the basal medium and the type and concentration of cytokinin on direct regeneration from internodal segments of passion flower (Passiflora edulis Sims). Internodal segment explants were cultured on the Murashige and Skoog (MS) and woody plant medium (WPM) without growth regulators or supplemented with $0.5-3.0 \mathrm{mg} \mathrm{L}^{-1}$ of 6-benzylaminopurine (BAP), thidiazuron (TDZ) or zeatin (ZEA). The cultivation of the internodal segment explants on media supplemented with cytokinins resulted in direct organogenesis without a callus phase. The shoot formation frequency and shoot number per explant were strongly influenced by the type and concentration of cytokinin. MS medium supplemented with BAP resulted in a shoot formation frequency that was higher in comparison with TDZ but significantly lower as compared to 0.5-2.5 mg L ${ }^{-1}$ ZEA. On the other hand, on WPM supplemented with BAP the shoot formation frequency was significantly lower in comparison with that for analogous ZEA and TDZ concentrations. The shoot formation frequency and shoot number per explant were strongly influenced by interactions of the basal medium and type and concentration of cytokinin. The MS medium supplemented with $2.0 \mathrm{mg} \mathrm{L}^{-1} \mathrm{ZEA}$ resulted in the highest shoot formation frequency, while the highest shoot number per explant was obtained on WPM supplemented with 1.5 $\mathrm{mg} \mathrm{L}^{-1}$ ZEA. The highest shoot formation frequency $(98.1 \%)$ with the highest number of shoots per explant (9.53) was observed on the WPM supplemented with $1.5 \mathrm{mg} \mathrm{L}^{-1} \mathrm{ZEA}$. The formed shoots were rooted on MS medium containing $1 / 2$ macro and micro salts supplemented with $2.0 \mathrm{mg} \mathrm{L}^{-1} \mathrm{IBA}$ (indole-3-butyric acid); about $92 \%$ of them survived and grew normally with true-to-type morphology.
\end{abstract}

Key words: basal medium, direct organogenesis, growth regulators, passion flower.

\section{Introduction}

Passion flower (Passiflora edulis Sims) is a very important horticultural plant that is increasingly being grown around the world for several purposes. In many tropical and subtropical climates, $P$. edulis is grown as an alternative to low-nutrition plants making it very important in the food industry. Due to its positive properties for human health, $P$. edulis has spread throughout the world. Various research groups have shown that $P$. edulis is characterized by anticonvulsant, anxiolytic and sedative (Coleta et al., 2006; Barbosa et al., 2008; Sena et al., 2009; Deng et al., 2010; Li et al., 2011), antioxidant (Ferreres et al., 2007; Sunitha, Devaki, 2009; Zeraik et al., 2011), blood pressure attenuating (Zibadi et al., 2007), anti-inflammatory (Zucolotto et al., 2009) and antibacterial (Kannan et al., 2011) activities. The anti-carcinogenic activity of $P$. edulis was studied by Li et al. (2013), who determined that the pulp, seed and peel showed 97, 97 and $89 \%$ inhibition, respectively of HT-29 (human colon adenocarcinoma cells) cancer cell line activity. According to Cazarin et al. (2015), the oral intake of aqueous extract of $P$. edulis leaves, which is a source of vitexin, isovitexin and isoorientin, significantly improved endogenous antioxidant status and decreased lipid peroxidation in the liver, colon and serum. In addition, $P$. edulis is valued as ornamental plant because of the great beauty of the flowers (Abreu et al., 2009).

The traditional propagation of $P$. edulis is very complicated, because this plant is characterized by low seed germination, seedling viability and growth rate. Besides this, $P$. edulis is sensitive to pathogenic microorganisms such as viruses, bacteria and fungi, which can significantly reduce plant productivity (Fischer, Rezende, 2008).

Because of these problems, it is important to find the most efficient way to propagate $P$. edulis through in vitro culture for the micropropagation of true-to-type plant regenerants from elite plants. In vitro micropropagation of the Passifloraceae family has been reported for some species such as Passiflora alata (Pinto et al., 2010), $P$. caerulea (Jafari et al., 2017) and P. foetida (Shekhawat

Please use the following format when citing the article:

Burbulis N., Blinstrubienė A., Petruškevičius A. 2021. In vitro propagation of Passiflora edulis through internodal segments as affected by medium composition. Zemdirbyste-Agriculture, 108 (4): 377-382. DOI 10.13080/z-a.2021.108.048 
et al., 2015 a). In vitro regeneration of $P$. edulis has been obtained from internodal segments (Biasi et al., 2000), leaf segments (Trevisan, Mendes, 2005), hypocotyl explants (Fernando et al., 2007), apical meristem (Prammanee et al., 2011) and root (da Silva et al., 2011) and nodal (Shekhawat et al., 2015 b) segments. In the study of Biasi et al. (2000), simultaneous callus and adventitious shoot formation from internodal segments with asynchronous development of shoots from explants on MS medium supplemented with BAP was observed. However, indirect shoot formation in many cases may create somaclonal variations; therefore, it cannot be used for the production of a genetically identical plants. To the best of our knowledge, the effect of basal medium and cytokinin interaction on direct organogenesis from internodal segments of $P$. edulis has not been reported before.

Therefore, the aim of the present study was to evaluate the effect of the basal medium and the type and concentration of cytokinin on direct regeneration from internodal segments of passion flower (Passiflora edulis Sims).

\section{Materials and methods}

Induction of in vitro organogenesis. The experiment was conducted in 2019-2020. Six-monthold donor passion flower (Passiflora edulis Sims) plants from Botanical Garden of Klaipeda University were maintained in a growth chamber with a $16 / 8 \mathrm{~h}$ photoperiod, $25 / 22^{\circ} \mathrm{C}$ (day/night) temperature and $100 \mu \mathrm{mol} \mathrm{m} \mathrm{m}^{-2} \mathrm{~s}^{-1}$ light density. Explants - internodal $20 \mathrm{~mm}$ long segments - were washed thoroughly under running tap water for $5 \mathrm{~min}$. The surfaces of explants were disinfected in $70 \%$ ethanol for $3 \mathrm{~min}$ and then in $5.0 \%$ active chlorine solution supplemented with $0.05 \%$ Tween 20 (Sigma-Aldrich) for $20 \mathrm{~min}$. They were then washed three times with sterile distilled water. For organogenesis induction, the explants were horizontally placed on Murashige and Skoog (MS) (Murashige, Skoog, 1962) or woody plant medium (WPM) (Lloyd, McCown, 1980) basal media without growth regulators or with $0.5,1.0,1.5,2.0,2.5$ and $3.0 \mathrm{mg} \mathrm{L}^{-1}$ of 6benzylaminopurine (BAP), thidiazuron (TDZ) or zeatin (ZEA). Basal media were supplemented with $30.0 \mathrm{~g} \mathrm{~L}^{-1}$ sucrose and $8.0 \mathrm{~g} \mathrm{~L}^{-1}$ agar, and the $\mathrm{pH}$ was adjusted to 5.7. Culture media $(20 \mathrm{~mL})$ were dispensed into $90 \mathrm{~mm}$ in diameter Petri dishes and then sealed with parafilm. Explants were cultivated in a growth chamber at $25 / 22^{\circ} \mathrm{C}$ (day/night) temperature under a $16 / 8 \mathrm{~h}$ photoperiod at

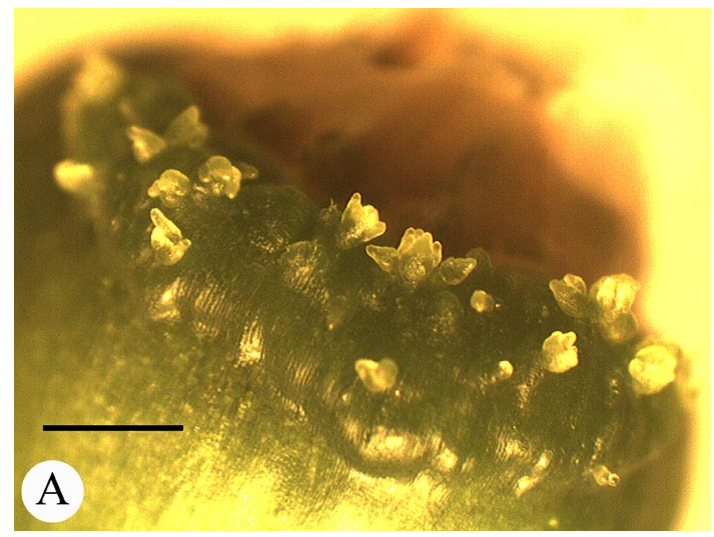

Bar $=1.0 \mathrm{~mm}$ a light intensity of $50 \mu \mathrm{mol} \mathrm{m} \mathrm{m}^{-2} \mathrm{~s}^{-1}$. Shoot formation frequency and adventitious shoot number per explant were recorded after 4 weeks of culture.

Shoot elongation, root formation and plantlet acclimatization. For elongation, regenerated shoots were removed from the explants and transferred to the same medium additionally supplemented with $1.2 \mathrm{mg} \mathrm{L}^{-1} \mathrm{GA}_{3}$ (gibberellic acid) and cultivated in the growth chamber under the same conditions as for organogenesis induction. For rooting, elongated shoots were transferred to MS medium containing $1 / 2$ macro and micro salts supplemented with $2.0 \mathrm{mg} \mathrm{L}^{-1} \mathrm{IBA}$ (indole-3-butyric acid) and $10.0 \mathrm{~g} \mathrm{~L}^{-1}$ sucrose. The medium was solidified with $8.0 \mathrm{~g} \mathrm{~L}^{-1}$ agar, and the $\mathrm{pH}$ was adjusted to 5.7. Regenerated shoots were cultivated at $25 / 22^{\circ} \mathrm{C}$ (day/night) under a $16 / 8 \mathrm{~h}$ photoperiod at a light intensity of $45 \mu \mathrm{mol} \mathrm{m}^{-2} \mathrm{~s}^{-1}$. Plantlets with roots were removed from the medium, washed with water to remove the medium from the roots and planted in plastic pots with perlite and vermiculite in a 1:1 ratio. The $P$. edulis plants were initially covered with a plastic bag and maintained in a growth chamber at $25 / 22^{\circ} \mathrm{C}$ (day/ night) under a $16 / 8 \mathrm{~h}$ photoperiod at a light intensity of $50 \mu \mathrm{mol} \mathrm{m}^{-2} \mathrm{~s}^{-1}$ for 14 days, and then they were transferred to the greenhouse.

The experiment was arranged in a completely randomized design with three replicates per treatment and 44 explants per replicate. The percentage of shoot formation frequency and the number of shoots per explant was calculated using the following formulas:

Shoot formation $(\%)=$ (number of explants with adventitious shoots / total number of explants $) \times 100$;

Number of shoots $=$ number of adventitious shoots / number of explants forming adventitious shoots.

Statistical analysis of the experimental data was done using the software package Statistica, version 10 (TIBCO Software, USA). The mean value of shoot formation frequency and corresponding standard error (SE) for every treatment were computed based on the number of independent replications. Fisher's least significant difference (LSD) test was carried out with a significance level of $p<0.05$.

\section{Results}

The internodal segments of Passiflora edulis that were grown on the medium without growth regulators demonstrated no response. Cultivation of the internodal explants on the medium supplemented with cytokinins resulted in direct organogenesis close to the cutting end (Figure 1).

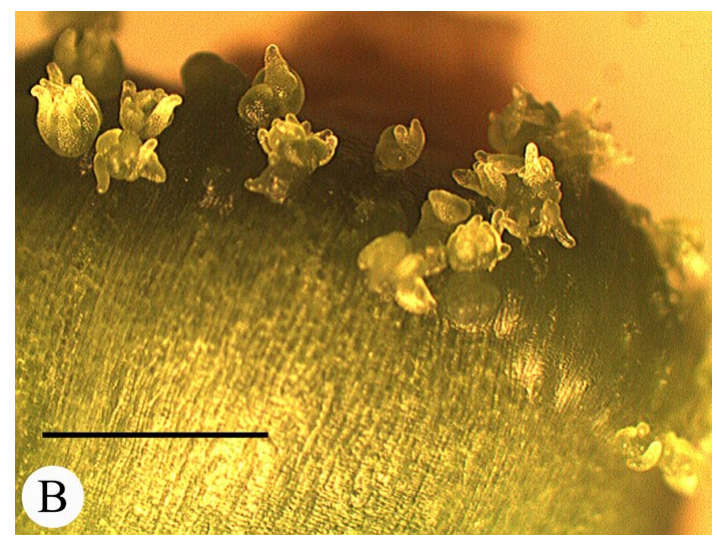

Figure 1. Initiations of adventitious Passiflora edulis shoots from internodal segments cultured on the MS (A) and WPM (B) basal media 
The adventitious shoot formation frequency varied from $26.4 \%$ to $98.4 \%$ depending on the basal medium and the type and concentration of the cytokinin (Figure 2).
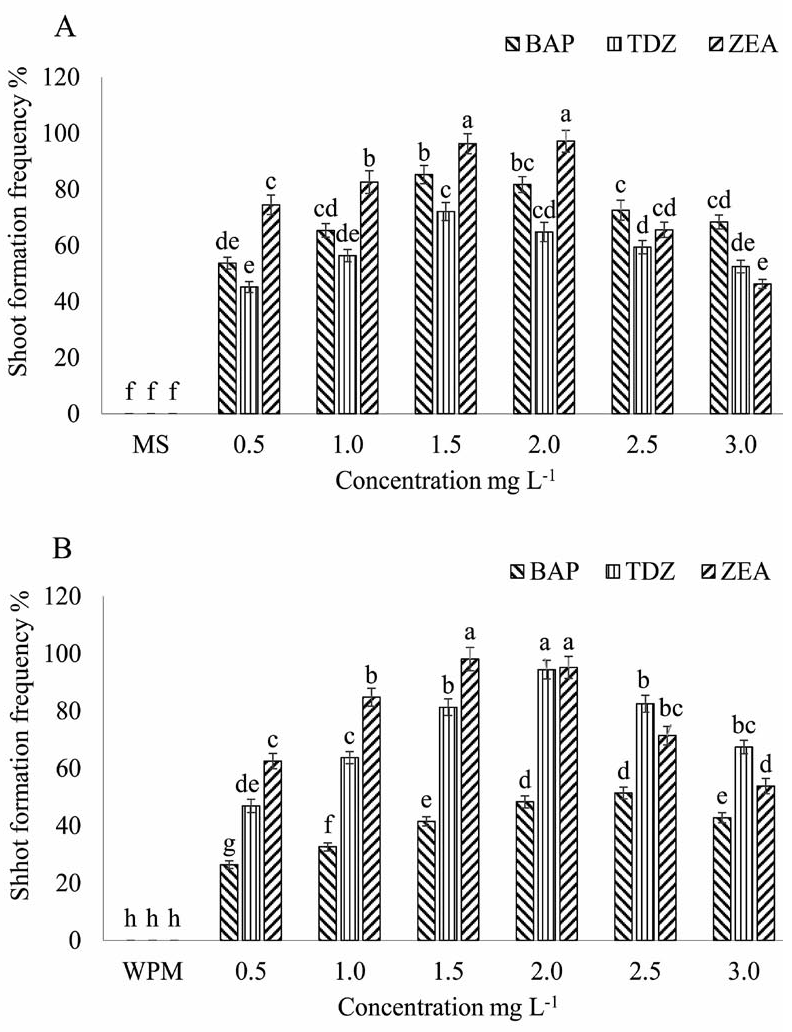

Note. BAP - 6-benzylaminopurine, TDZ - thidiazuron, ZEA - zeatin; values with the same letter do not significantly differ at $p>0.05$; the bars above the columns denote the standard errors.

Figure 2. Effect of basal medium and cytokinin type and concentration on Passiflora edulis shoot formation frequency on the MS (A) and WPM (B)

On the MS medium supplemented with BAP, the shoot formation frequency varied from $53.7 \%$ to $85.3 \%$ (Figure 2) with in average of $71.18 \%$ (Table), while the incorporation of BAP into WPM promoted average shoot formation of $40.5 \%$. The addition of TDZ to both tested basal media resulted in average shoot formation frequency of $58.4 \%$ on MS and $72.7 \%$ on WPM. On the MS and WPM media supplemented with ZEA, average shoot formation frequencies were $77.08 \%$ and $77.63 \%$, respectively.

The shoot formation frequency was strongly influenced by the type and concentration of cytokinin. Polynomial regression analysis showed that the highest shoot formation frequency was observed on MS medium at $2.0 \mathrm{mg} \mathrm{L}^{-1}$ ZEA $\left(\mathrm{y}=-8.294 \mathrm{x}^{2}+71.242 \mathrm{x}-52.843\right.$; $\left.R^{2}=0.9134\right)$, while on WPM it was observed at $1.5 \mathrm{mg} \mathrm{L}^{-1}$ ZEA $\left(\mathrm{y}=-11.473 \mathrm{x}^{2}+88.71 \mathrm{x}-72.79 ; R^{2}=0.9514\right)$.

The number of shoots per explant varied from 3.41 to 9.63 depending on the basal medium and the type and concentration of the cytokinin (Figure 3 ).
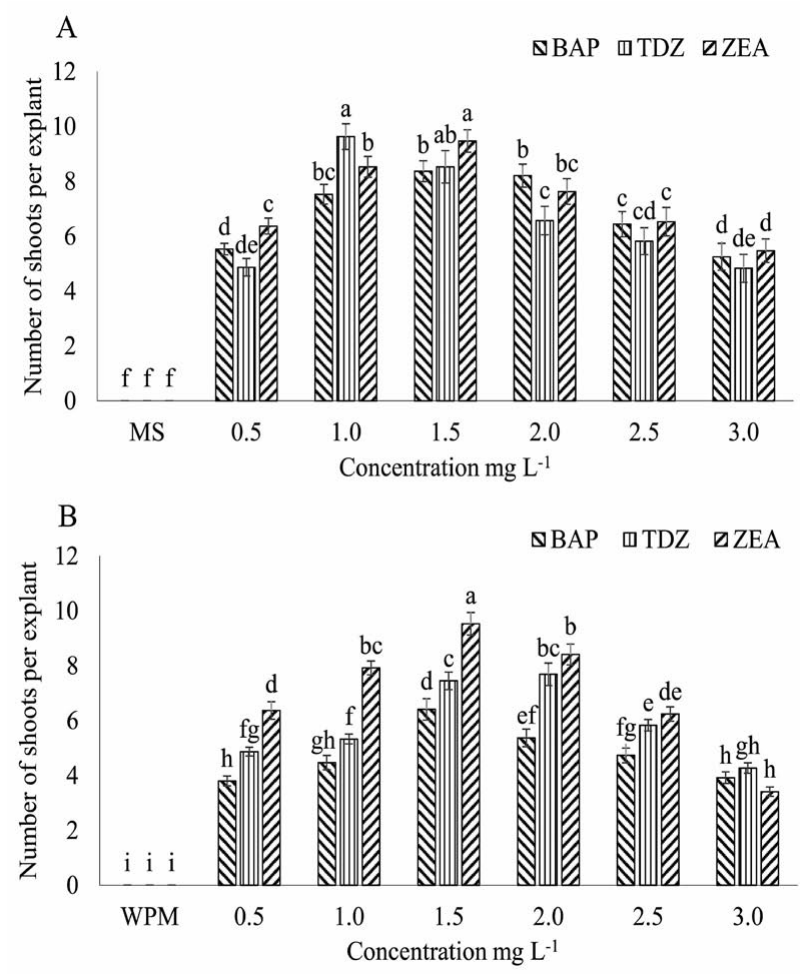

Note. BAP - 6-benzylaminopurine, TDZ - thidiazuron, ZEA - zeatin; values with the same letter do not significantly differ at $p>0.05$; the bars above the columns denote the standard errors.

Figure 3. Effect of basal medium and cytokinin type and concentration on the number of Passiflora edulis shoots per explant on the MS (A) and WPM (B)

The addition of BAP to the MS medium resulted in an average of 6.89 shoots per explant, while addition of this cytokinin to the WPM resulted in a lower shoot number per explant by an average of 4.78 (Table). In the MS medium, the influence of TDZ on the shoot number per explant was similar to that of BAP, and each explant formed on average 6.71 shoots. On the other hand, on the WPM, TDZ promoted a higher (5.91) average shoot number per explant in comparison with BAP. ZEA was superior to BAP and TDZ in both tested basal media with average shoot numbers per explant of 7.33 on MS and 6.98 on WPM.

Table. Effect of basal medium and cytokinin type on mean values of Passiflora edulis shoot formation frequency and number of shoots per explant

\begin{tabular}{ccccc}
\hline \multirow{2}{*}{$\begin{array}{c}\text { Type of } \\
\text { cytokinin }\end{array}$} & \multicolumn{3}{c}{ MS } & \multicolumn{2}{c}{ WPM } \\
\cline { 2 - 5 } & $\begin{array}{c}\text { shoot formation } \\
\text { frequency } \%\end{array}$ & $\begin{array}{c}\text { number of shoots } \\
\text { per explant }\end{array}$ & $\begin{array}{c}\text { shoot formation } \\
\text { frequency } \%\end{array}$ & $\begin{array}{c}\text { number of shoots } \\
\text { per explant }\end{array}$ \\
\hline Control & 0.00 & 0.00 & 0.00 & 0.00 \\
BAP & 71.18 & 6.89 & 40.50 & 4.78 \\
TDZ & 58.40 & 6.71 & 72.70 & 5.91 \\
ZEA & 77.08 & 7.33 & 77.63 & 6.98 \\
\hline
\end{tabular}

BAP - 6-benzylaminopurine, TDZ - thidiazuron, ZEA - zeatin; MS - Murashige and Skoog, WPM - woody plant medium 


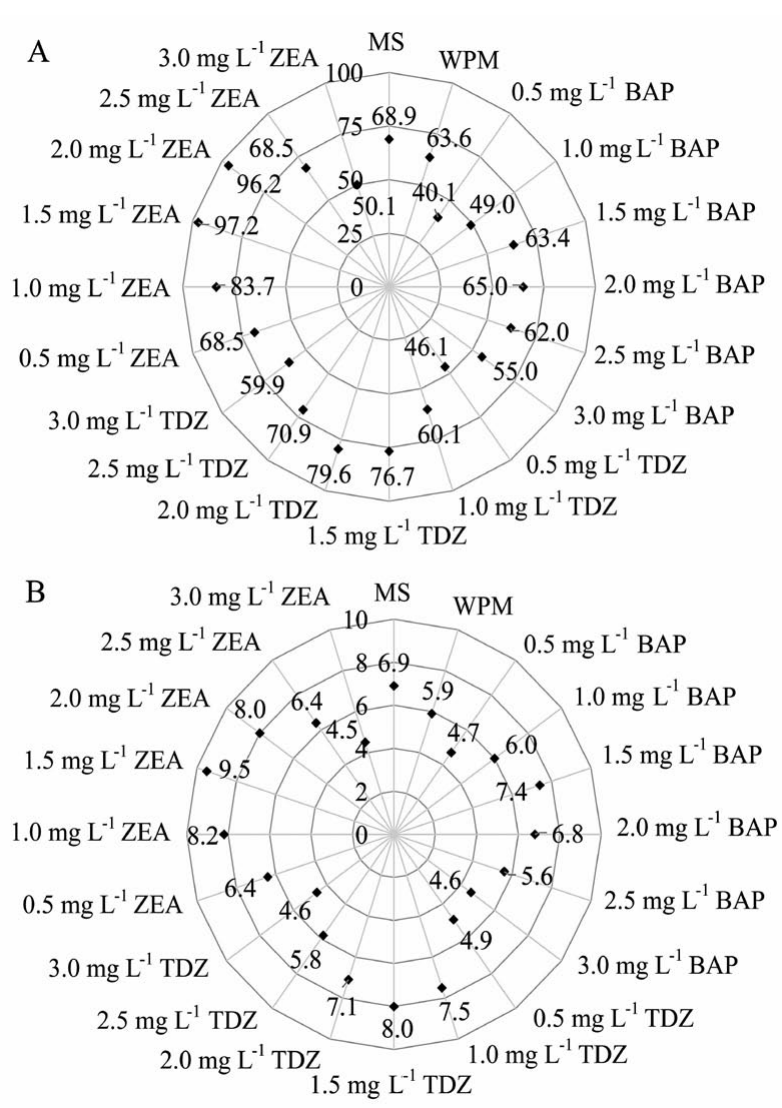

BAP - 6-benzylaminopurine, TDZ - thidiazuron, ZEA - zeatin

Figure 4. Average shoot formation frequency (A) and average number of Passiflora edulis shoots per explant (B) depending on the basal medium, type and concentration of cytokinin
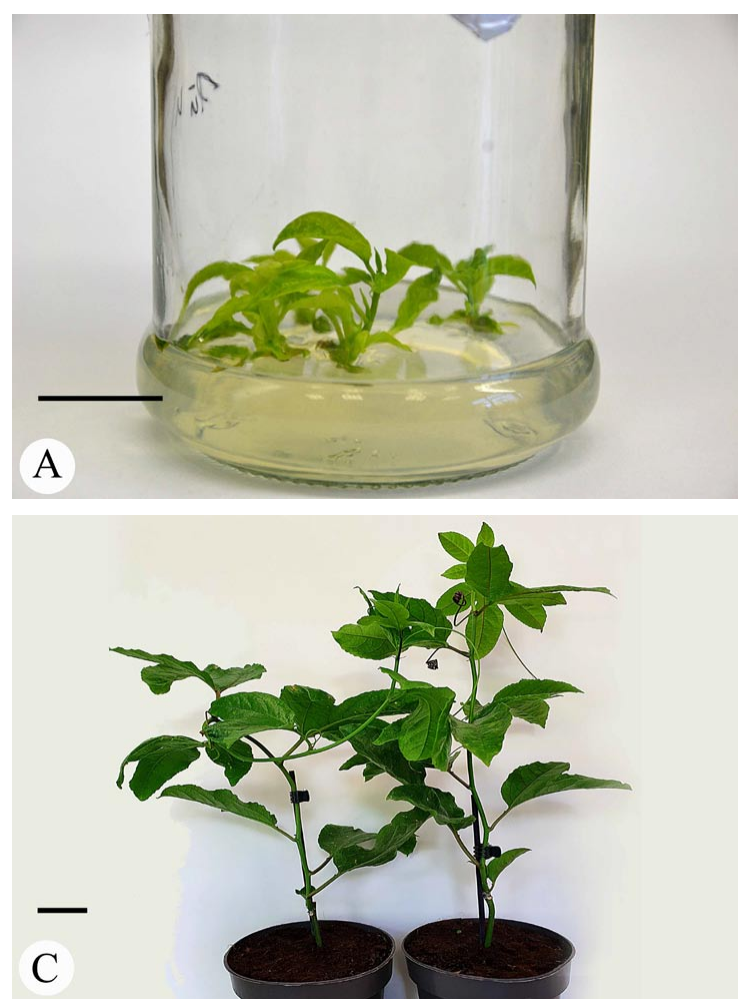

Polynomial regression analysis showed that on MS medium the highest shoot number per explant was observed at $1.0 \mathrm{mg} \mathrm{L}^{-1} \mathrm{TDZ}\left(\mathrm{y}=-0.6973 \mathrm{x}^{2}+6.0542 \mathrm{x}-4.5214 ; R^{2}=\right.$ $0.8115)$, while on WPM it was observed at $1.5 \mathrm{mg} \mathrm{L}^{-1} \mathrm{ZEA}$ $\left(\mathrm{y}=-0.834 \mathrm{x}^{2}+7.046 \mathrm{x}-5.52 ; R^{2}=0.9612\right)$.

The evaluation of separate factors affecting organogenesis response in the tested explants showed that the MS medium was superior to the WPM in terms of both shoot formation frequency and the number of shoots per explant. The average shoot formation frequencies on MS and WPM were $68.9 \%$ and $63.6 \%$, respectively (Figure 4A) with average shoot number per explant of 6.9 and 5.9, respectively (Figure 4B). The average shoot formation frequency was strongly dependent on the tested cytokinin concentration. Increased cytokinin concentration up to $2.0 \mathrm{mg} \mathrm{L}^{-1} \mathrm{BAP}$ and $\mathrm{TDZ}$ or up to $1.5 \mathrm{mg} \mathrm{L}^{-1} \mathrm{ZEAresulted} \mathrm{in} \mathrm{an} \mathrm{increased} \mathrm{average} \mathrm{percentage}$ of responding explants with subsequent decreasing average shoot formation frequency under the influence of higher concentrations of cytokinins (Figure 4A). All tested cytokinins induced the highest average shoot number per explant at $1.5 \mathrm{mg} \mathrm{L}^{-1}$ (Figure 4B).

On the elongation medium, the regenerated shoots were elongated within 21 days (Figure 5A). The formed roots were observed within 4 weeks on the rooting medium, about $98 \%$ of shoots developed roots (Figure 5B). P. edulis plants with roots were transferred to the greenhouse; about $92 \%$ of them survived (Figure 5C) and grew normally with true-to-type morphology (Figure 5D).
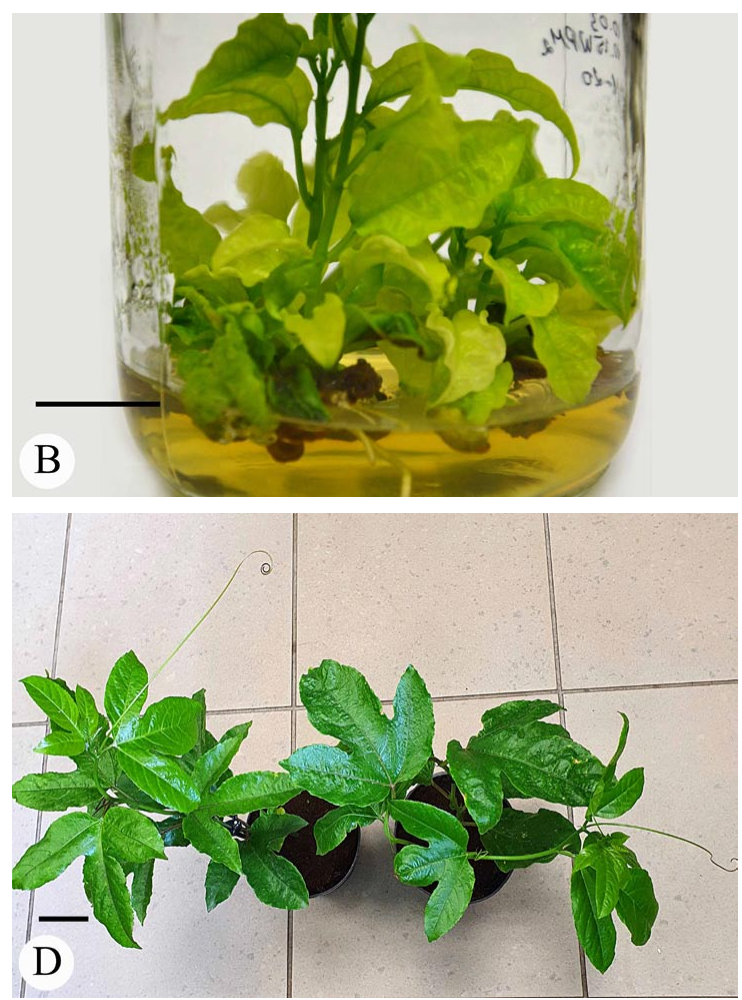

Bars: A, B $=2 \mathrm{~cm} ; \mathrm{C}, \mathrm{D}=5 \mathrm{~cm}$

Figure 5. Elongated shoots on the elongation medium (A), rooted shoots on the rooting medium (B) and hardened Passiflora edulis plants (C, D) 


\section{Discussion}

The culture medium composition is one of the most important factors affecting somatic tissue response throughout cultivation in vitro. WPM has been suggested to be more suitable for the micropropagation of some horticultural plants, for example, Vaccinium corymbosum, $V$. vitis-idaea and $V$. virgatum (Meiners et al., 2007; Schuchovski, Biasi, 2019). In our investigation, internodal segments of Passiflora edulis cultured on the MS medium showed greater average organogenic response than did explants cultured on the WPM.

A very important factor for organogenesis induction also is the type and concentration of growth regulators in the culture medium. Prammanee et al. (2011) reported that a higher number of shoots from the apical meristem of $P$. edulis was obtained on MS medium supplemented with 1.0 and $1.5 \mathrm{mg} \mathrm{L}^{-1} \mathrm{BA}$ (benzyladenine). In their study, the medium with $1.5 \mathrm{mg} \mathrm{L}^{-1} \mathrm{BA}$ generated more numerous but shorter shoots in comparison with the medium supplemented with $1.0 \mathrm{mg} \mathrm{L}^{-1} \mathrm{BA}$, where shoots were longer and, therefore, more suitable for sub-cultivation. For shoot formation from thin cell layer explants of $P$. edulis, $1.0 \mathrm{mg} \mathrm{L}^{-1} \mathrm{BA}$ was suggested in the study by Nhut et al. (2007). Jafari et al. (2017) reported that the combination of $1.5 \mathrm{mg} \mathrm{L}^{-1} \mathrm{BAP}$ and $0.15 \mathrm{mg} \mathrm{L}^{-1}$ IBA promoted the highest regeneration frequency with the highest number of shoots from cotyledonary node and shoot tip explants of $P$. caerulea, while semi-solid MS medium supplemented with $2.0 \mathrm{mg} \mathrm{L}^{-1} \mathrm{BAP}$ was found to be most appropriate for shoot formation from nodal shoot meristems of $P$. foetida (Shekhawat et al., 2015 a).

According to the research reports, TDZ stimulates direct organogenesis from the somatic tissues of blackberry (Vujović et al., 2010) and strawberry (Cappelletti et al., 2016). The higher number of shoots per explant from leaf discs of $P$. edulis obtained using TDZ as compared to BAP was obtained in studies by Trevisan and Mendes (2005). Kumar et al. (2010) reported that TDZ shows greater influence on shoot regeneration from cotyledonary leaf explants of Jatropha curcas as compared to BAP. ZEA was suggested as a more appropriate cytokinin for direct organogenesis in blueberry (Welander et al., 2017; Schuchovski, Biasi, 2019).

In our experiment, MS and WPM supplemented with ZEA resulted in a shoot formation frequency that was higher in comparison with BAP and TDZ. The highest shoot formation frequency on MS medium was obtained at $2.0 \mathrm{mg} \mathrm{L}^{-1} \mathrm{ZEA}$, while $1.5 \mathrm{mg} \mathrm{L}^{-1} \mathrm{ZEA}$ resulted in the highest shoot formation frequency on the WPM. The highest shoot number per explant on MS medium was observed under the influence of $1.0 \mathrm{mg} \mathrm{L}^{-1} \mathrm{TDZ}$, and on WPM it was observed with $1.5 \mathrm{mg} \mathrm{L}^{-1} \mathrm{ZEA}$.

The results obtained in our experiment clearly demonstrate that WPM supplemented with $1.5 \mathrm{mg} \mathrm{L}^{-1}$ ZEA is most appropriate for micropropagation of $P$. edulis from internodal segments.

\section{Conclusions}

1. The cultivation of the internodal segment explants of passion flower (Passiflora edulis Sims) on the basal media supplemented with cytokinins resulted in direct organogenesis without a callus phase.

2 . The shoot formation frequency and shoot number per explant were strongly influenced by the type and concentration of cytokinin. Murashige and Skoog (MS) medium supplemented with 6-benzylaminopurine (BAP) resulted in a shoot formation frequency that was higher in comparison with thidiazuron (TDZ) but significantly lower as compared to zeatin (ZEA) at 0.5
$2.5 \mathrm{mg} \mathrm{L}^{-1}$ concentration. On the other hand, on woody plant medium (WPM) supplemented with BAP the shoot formation frequency was significantly lower in comparison with that for analogous ZEA and TDZ concentrations.

3. The shoot formation frequency and shoot number per explant were strongly influenced by the interactions of the basalmediumand typeand concentration of cytokinin. The MS medium supplemented with $2.0 \mathrm{mg}$ $\mathrm{L}^{-1}$ ZEA resulted in the highest shoot formation frequency, while the highest shoot number per explant was obtained on WPM supplemented with $1.5 \mathrm{mg} \mathrm{L}^{-1} \mathrm{ZEA}$.

Received 01072021 Accepted 23082021

\section{References}

Abreu P. P., Souza M. M., Santos E. A., Pires M. V., Pires M. M., de Almeida A.-A. F. 2009. Passion flower hybrids and their use in the ornamental plant market: perspectives for sustainable development with emphasis on Brazil. Funhytica, 166: 307-315. https://doi.org/10.1007/s10681-008-9835-x

Barbosa P. R., Valvassori S. S., Bordignon Jr. C. L., Kappel V. D., Martins M. R., Gavioli E. C., Quevedo J., Reginatto F.H. 2008. The aqueous extracts of Passiflora alata and Passiflora edulis reduce anxiety-related behaviors without affecting memory process in rats Inurnal of Medicinal Food, 11 (2): 282-288. https://doi.org/10.1089/jmf.2007.722

Biasi L. A., Falco M. C., Rodriguez A. P. M., Mendes B. M. J. 2000. Organogenesis from internodal segments of yellow nassion fruit Scientia A oricola 57 661-665.

https://doi.org/10.1089/jmf.2007.7220

Cappelletti R., Sabbadini S., Mezzetti B. 2016. The use of TDZ for the efficient in vitro regeneration and organogenesis of strawberry and hlueherry cultivars. Scientia Horticulturae, 207: 117-124. https://doi.org/10.1016/j.scienta.2016.05.016

Cazarin C. B. B., da Silva J. K., Colomeu 'I. C., Batista A. G., Meletti L. M. M., Paschoal J. A. R., Bogusz Jr. S., de Campos Braga P. A., Reyes F. G. R., Augusto F., de Meirelles L. R., de Lima Zollner R., Maróstica Jr. M. R. 2015. Intake of Passiflora edulis leaf extract improves antioxidant and anti-inflammatory status in rats with 2,4,6trinitrobenzenesulphonic acid induced colitis. Journal of Functional Fonds 17. 575-586 https://doi.org/10.1016/j.jff.2015.05.034

Coleta M., Batista M. I., Campos M. G., Carvalho R., Cotrim M. D., de Lima T. C. M., da Cunha A. P. 2006. Neuropharmacological evaluation of the putative anxiolytic effects of Passiflora edulis Sims, its sub-fractions and flavonoid constituents. Phytotherany Research, 20 (12): 1067-1073. https://doi.org/10.1002/ptr.1997

da Silva C. V., de Oliveira L. S., Loriato V. A. P., da Silva L. C., de Campos J. M. S., Viccini L. F., de Oliveira E. J., Otoni W. C. 2011. Organogenesis from root explants of commercial populations of Passiflora edulis Sims and a wild passionfruit species, P. cincinnata Masters. Plant Cell, Tissue and Organ Culture $107 \cdot 407-416$ https://doi.org/10.1007/s11240-011-9991-x

Deng J., Zhou Y., Bai M., Li H., Li L. 2010. Anxiolytic and sedative activities of Passiflora edulis f. flavicarpa. Journal of Fthnonharmacology. 128 (1): 148-153. https://doi.org/10.1016/j.jep.2009.12.043

Fernando J. A., Vieira M. L. C., Machado S. R., Appezzato-daGloria B. 2007. New insights into the in vitro organogenesis process: the case of Passiflora. Plant Cell, Tissue and Organ Culture $91 \cdot 37-44$ https://doi.org/10.1007/s11240-007-9275-7

Ferreres F., Sousa C., Valentão P., Andrade P. B., Seabra R. M., Gil-Izquierdo A. 2007. New C-deoxyhexosyl flavones and antioxidant properties of Passiflora edulis leaf extract. Journal of Agricultural and Fond Chemistry, 55 (25): 10187-10193. https://doi.org/10.1021/jf072119y

Fischer I. H., Rezende J. A. M. 2008. Diseases of passion flower (Passiflora spp.). Pest Technology, 2: 1-19.

Jafari M., Daneshvar M. H., Lotfi A. 2017. In vitro shoot proliferation of Passiflora caerulea L. via cotyledonary node and shont tin explants. BinTechnolngia, 98 (2): 113119. https://doi.org/10.5114/bta.2017.68310 
Kannan S., Parimala Devi B., Jayakar B. 2011. Antibacterial evaluation of the methanolic extract of Passiflora edulis. Hygeia. Inurnal of Drugs and Medicines, 3 (1): 46-49. https://doi.org/10.1155/2014/167309

Kumar N., V1jay Anand K. G., Keddy M. P. 2010. Shoot regeneration from cotyledonary leaf explants of Jatropha curcas: a hindiecel nlant Acta Physiolnoiae Plantarım, 32: 917-924. https://doi.org/10.1007/s11738-010-0479-9

Li H., Zhou P., Yang Q., Shen Y., Deng J., Li L., Zhao D. 2011. Comparative studies on anxiolytic activities and flavonoid compositions of Passiflora edulis 'edulis' and Passiflora edulis 'flavicarna' Inurnal of F.thnnnharmacolngy, 133 (3): 1085-1090. https://doi.org/10.1016/j.jep.2010.11.039

Li F., Li S., Li H.-B., Deng G.-H., Ling W.-H., Wu S., Xu X.-R., Chen F. 2013. Antiproliferative activity of peels, pulps and seeds of 61 fruits Inurnal of Functional Fonds 5 (3): 1298 1309. https://doi.org/10.1016/j.jff.2013.04.016

Lloyd G., Mccown B. 1980. Commercially-feasible micropropagation of mountain laurel, Kalmia latifolia, by use of shoot-tip culture. Proceedings of the International Plant Propagators' Society, 30: 421-426.

Meiners J., Schwab M., Szankowski I. 2007. Efficient in vitro regeneration systems for Vaccinium species. Plant Cell, Tissue and Organ Culture, 89 (?-3): 169-176. https://doi.org/10.1007/s11240-007-9230-7

Murashige I., Skoog F. 1962. A revised medium for rapid growth and bio assays with tobacco tissue cultures. Physiolngia Plantanum 15 (3) $473-497$ https://doi.org/10.1111/j.1399'-3054.1962.tb08052.x

Nhut D. I., Khiet B. L. I., Ih1 N. N., I huy D. I. I., Duy N., Hai N. T., Huyen P. X. 2007. High frequency shoot formation of yellow passion fruit (Passiflora edulis f. flavicarpa) via thin cell layer (TCL) technology. Jain S. M., Häggman H. (eds). Protocols for Micropropagation of Woody Trees and Fruits Snringer, chanter 38, n 417-476 https://doi.org/10.1007/978-1-4020-6352-7 38

Pinto A. P. C., Monteiro-Hara A. C. B. A., Stipp L. C. L., Mendes B. M. J. 2010. In vitro organogenesis of Passiflora alata. In Vitro Cellular and Develnnmental Rinlngy - Plant, 46: 28-33. https://doi.org/10.1007/s11627-009-9251-5

Prammanee S.,' I humjamras S., Chiemsombat P., Pipattanawong N. 2011. Efficient shoot regeneration from direct apical meristem tissue to produce virus-free purple passion fruit nlants Cron Protection, $30(11) \cdot 1475-1429$ https://doi.org/10.1016/j.cropro.2011.07.008

Schuchovski C. S., Biasi L. A. 2019. In vitro establishment of 'Delite' rahhiteye hlueherry microshonts Horticulturae, 5 (1): 24. https://doi.org/10.3390/horticulturae5010024

Sena L. M., Zucolotto S. M., Reginatto F. H., Schenkel E. P., De Lima T. C. M. 2009. Neuropharmacological activity of the pericarp of Passiflora edulis flavicarpa degener: Putative involvement of C-glycosyl flavonoids. Experimental Biology and Medicine, 234 (8): 967-975.

https://doi.org/10.3181/0902-RM-84

Shekhawat M. S., Kannan N., Manokari M., Ravindran C. P. 2015 (a). In vitro regeneration of shoots and ex vitro rooting of an important medicinal plant Passiflora foetida L. through nodal segment cultures. Journal of Genetic Engineering and Rintechnolngy $13($ ) $) \cdot$. $09-7.14$

https://doi.org/10.1016/j.jgeb.2015.08.002

Shekhawat M. S., Manokari M., Kavindran C. P. 2015 (b). An improved micropropagation protocol by ex vitro rooting of Passiflora edulis Sims. f. flavicarpa Deg. through nodal segment culture. Scientifica, 2015: 578676. https://doi.org/10.1155/2015/578676

Sunitha M., Devaki K. 2009. Antioxidant activity of Passiflora edulis Sims leaves. Indian Journal of Pharmaceutical Sciences, 71 (3): $310-311$. https://doi.org/10.4103/0250-474X.56038

Trevisan F., Mendes B. M. J. 2005. Optimization of in vitro organogenesis in passion fruit (Passiflora edulis f. flavicarna) Scientia A oricola 67 (4) $346-350$ https://doi.org/10.1590/S0103-90162́005000400007

Vujović I., Ruzić D., C'erović R., Momirović G. S. 2010. Adventitious regeneration in blackberry (Rubus fruticosus L.) and assessment of genetic stability in regenerants Plant frowth Regulation 61.265-275. https://doi.org/10.1007/s10725-010-9474-9

Welander M., Sayegh A., Hagwall F., Kuznetsova T., Holefors A. 2017. Technical improvement of a new bioreactor for large scale micropropagation of several Vaccinium cultivars. Acta Horticulturae, 1180. 387-39? https://doi.org/10.17660/ActaHortic.2017.1180.53

Zeraik M. L., Serteyn D., Deby-Dupont G., Wauters J.-N., Tits M., Yariwake J. H., Angenot L., Franck T. 2011. Evaluation of the antioxidant activity of passion fruit (Passiflora edulis and Passiflora alata) extracts on stimulated neutrophils and myeloperoxidase activity assays. Fond Chemistry $178(7) \cdot 259-765$ https://doi.org/10.1016/j.foodchem.2011.03.001

Zibadi S., Farid R., Moriguchi S., Lu Y., Foo L. Y., Tehrani P. M., Ulreich J. B., Watson R. R. 2007. Oral administration of purple passion fruit peel extract attenuates blood pressure in female spontaneously hypertensive rats and humans. Nutrition Research, 27 (7): 408-416 https://doi.org/10.1016/j.nutres.2007.05.004

Zucolotto S. M., Goulart S., Montanher A. B., Reginatto F. H., Schenkel E. P., Fröde T. S. 2009. Bioassay-guided isolation of anti-inflammatory C-glucosyl flavones from Passiflora

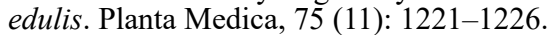
https://doi.org/10.1055/s-0029-1185536

\title{
Maitinamosios terpès sudèties poveikis Passiflora edulis dauginimui in vitro tarpubamblių segmentų kultūroje
}

\author{
N. Burbulis, A. Blinstrubienė, A. Petruškevičius \\ Vytauto Didžiojo universiteto Žemès ūkio akademija
}

\section{Santrauka}

Tyrimo tikslas - nustatyti bazinès maitinamosios terpès, citokinino tipo ir koncentracijos poveiki pasifloros (Passiflora edulis Sims) tiesioginei regeneracijai tarpubambliu segmentu kultūroje. Tarpubamblių segmentu eksplantai buvo auginti Murashige ir Skoog (MS) ir sumedejjusių augalu (WPM) terpèse be augimo reguliatoriu ir papildytose 0,5-3,0 $\mathrm{mg} \mathrm{L}^{-1}$ 6-benzilaminopurino (BAP), tidiazurono (TDZ) ir zeatino (ZEA). Citokininu priedas maitinamojoje terpèje skatino tiesioginę organogenezę be tarpinès kaliaus fazès. Ūglių susiformavimo dažnis ir kiekis iš eksplanto kito priklausomai nuo citokinino tipo bei koncentracijos. BAP priedas MS terpèje ūgliu susiformavimo dažni skatino labiau nei TDZ, tačiau esmingai mažiau nei ZEA. Kita vertus, BAP priedas WPM terpejje ūgliu susiformavimo dažnį skatino esmingai mažiau nei analogiškos ZEA ir TDZ koncentracijos. Be to, nustatyta priklausomybè tarp bazinès terpès, citokinino tipo, koncentracijos sąveikos ir ūglių susiformavimo dažnio bei üglių kiekio iš eksplanto. Didžiausias ūglių susiformavimo dažnis $(98,1 \%)$ ir didžiausias ūglių kiekis iš eksplanto $(9,53)$ gautas WPM maitinamojoje terpeje, papildytoje $1,5 \mathrm{mg} \mathrm{L}^{-1}$ ZEA. Susiformavę ūgliai buvo įšaknydinti $1 / 2 \mathrm{MS}$ terpeje, papildytoje $2,0 \mathrm{mg} \mathrm{L}^{-1}$ ISR (indolil-3-sviesto rūgšties). Apie $92 \%$ jų išgyveno aklimatizacijos metu ir buvo morfologiškai identiški donoriniams augalams.

Reikšminiai žodžiai: bazinè terpè, tiesioginè organogenezè, augimo reguliatoriai, pasiflora. 